\title{
Pola Komunikasi Terapeutik Perawat dan Pasien Hemodialisis
}

\author{
Rini Rinawati
}

\begin{abstract}
The poor quality of communication between nurses and patients have caused some malpractice cases. This research aimed to explore verbal and nonverbal language as expressed by nurses in a hemodialysis service unit in local hospital. Employing direct participant observation in conjunction with formal interview, informal interview, and literature review, this research focused on the concept of theurapetic communication defined by Samovar. It is found that the verbal language are clear, concise, explicit, and easily understood. The body language was expressed through nurse's presence-a strong indication of caring and empathy. Touch was another language often use to help patients heal their pains throughout hemodialysis process.
\end{abstract}

Kata kunci: komunikasi terapetik, pasien, perawat, bahasa verbal, bahasa nonverbal

\section{Pendahuluan}

\subsection{Latar Belakang Masalah}

Belum lama ini, keluarga almarhumah Sukma Ayu mengajukan gugatan atas dugaan malapraktik (medical malpractice) atau kesalahan/kelalaian dalam menjalankan praktek medis yang dilakukan tenaga medis RS Medistra Jakarta. Kasus ini bukan yang pertama terjadi di Indonesia. Dalam beberapa tahun terakhir, berdasarkan pengaduan dari masyarakat ke Yayasan Pemberdayaan Konsumen Kesehatan Indonesia (YPKKI), ada 149 kasus yang masuk. Bahkan, 75 persen dari yang melapor adalah tenaga kesehatan yang menjadi konsumen. Kejadian yang menimpa Sukma, hanyalah satu contoh dari sekian banyak kasus akibat ketidakberdayaan seorang pasien dan anggota keluarganya dalam menghadapi pelayanan medis, yang pada awalnya sangat ia butuhkan. Umumnya, pasien berada dalam kondisi dan posisi yang lemah, sehingga sangat tergantung kepada pihak lain.

Bila merujuk UU PK, Indah Suksmaningsih, Ketua Yayasan Lembaga Konsumen Indonesia (YLKI), mengatakan, kesalahan utama dari pelayan kesehatan adalah tidak adanya komunikasi antara dokter/perawat dengan pasien. Padahal, konsumen punya hak atas informasi itu. Dokter seharusnya menyampaikan informed consent, semacam pemberitahuan tentang penyakit pasien, tindakan yang akan dilakukan dan risiko apa yang mungkin terjadi dari suatu tindakan, sebelum tindakan itu 
dilakukan. http://www.pikiran-rakyat.com.

Hal senada diungkapkan Veronica, "Keluhan yang paling umum disampaikan para pasien beserta keluarganya di RS, terletak pada kurangnya komunikasi antara petugas RS dengan pasien dan keluarganya. Padahal, pasien sangat membutuhkan informasi mengenai diagnosis, prosedur medis, prognosa (perjalanan) penyakit, dan kondisi pasien lainnya. Memang, jika kita tinjau dari sudut pihak petugas RS, umumnya mereka akan mengendalikan informasi tentang kondisi pasien. Pasien tidak akan diberitahu tentang prognosa penyakitnya. (:http:/ /www.pikiran-rakyat.com).

Bahkan, kadang-kadang, petugas RS tidak segan-segan memutuskan komunikasi dengan pasien bila mereka merasa pasien mengetahui kekurangan atau kesalahan mereka dalam memberikan pelayanan medis. Pihak RS pasti akan berusaha menutup rapat-rapat kekurangan yang telah mereka lakukan terhadap pasien. Jika terdapat pertanyaan dari pasien atau keluarganya, para petugas RS cenderung menjawab dengan cara menghindar atau dengan cara menggunakan istilah-istilah medis yang sulit dimengerti orang awam. Mereka menganggap, lebih baik pasien atau keluarganya mencari tahu sendiri jawabannya secara alamiah. Dengan mencari informasi ke sana ke mari, memang pada akhirnya pihak pasien dan keluarganya akan sedikit paham mengenai penyakitnya. Celakanya lagi, banyaknya mitos dan kabar burung yang beredar di masyarakat seputar dunia kesehatan membuat pasien dibanjiri dengan informasi yang menyesatkan.

Bagaimanapun, tenaga medis harus menghormati hak pasien. Pasien berhak atas persetujuan tindakan yang dilakukan pada tubuhnya, hak atas rahasia dokter, hak atas informasi, dan hak atas second opinion. Jadi, alasan dokter bahwa para keluarga pasien tidak akan mampu memahami prognosa yang dijelaskan kepada mereka, dianggap keliru. Apalagi sampai menghindar, memutarbalikkan kenyataan, dan tibatiba menghentikan pembicaraan dengan keluarga pasien.

Pasien, karena keawamannya, memang selalu menyerahkan nasib sepenuhnya kepada dokter atau rumah sakit, atau mungkin bersikap cuek dan "potong kompas" dengan mengobati dirinya sendiri. Bahkan karena ketakutannya terhadap dokter, ada pasien yang menempuh jalur pengobatan alternatif. Dengan ketidaktahuan ini, pasien seringkali bingung menghadapi masalah kesehatan yang dihadapinya. Di samping itu, pola komunikasi yang cenderung hanya satu arah menyebabkan pengobatan yang dilakukan sering kali tidak efektif. Bahkan, dengan sikap para petugas kesehatan yang arogan, membuat pasien enggan bertanya tentang penyakit yang dideritanya dan bagaimana penyembuhannya.

Sehat memang merupakan nikmat yang tidak terhingga yang dikaruniakan Allah kepada kita sebagai mahluk-Nya. Kita wajib mensyukuri nikmat sehat yang telah diberikan Allah. Namun, sebagai manusia, tidak selamanya kita mengalami sehat. Dalam perjalanan kehidupannya, manusia akan mengalami apa yang dinamakan sakit. Penyakit yang diderita manusia sangat beragam, mulai dari yang ringan seperti flu sampai yang berat seperti kanker, atau dari yang bisa disembuhkan seperti batuk/pilek sampai yang tidak bisa disembuhkan berdasarkan perhitungan manusia, seperti gagal ginjal.

Gagal ginjal adalah tidak berfungsinya organ tubuh manusia yang fital, yaitu ginjal, sehingga organ tersebut tidak bisa menyaring racun yang ada dalam tubuh manusia. Oleh karena itu, pasien gagal ginjal perlu menjalani hemodialisis atau dikenal dengan cuci darah untuk menghilangkan racun yang ada dalam tubuhnya (wawancara dengan Asep, kepalaPelatihan Hemodialisis RSU Hasan Sadikin, Bandung).

Gagal Ginjal merupakan salah satu jenis penyakit kronik, sehingga selanjutnya disebut sebagai gagal ginjal kronik (GGK). GGk ini akan menimbulkan perubahan yang permanen pada kehidupan setiap individu. Ketika seseorang divonis menderita GGK, maka hemodialisis (cuci darah) menjadi pilihan karena yang terbaik adalah melakukan tranplantasi (cangkok) ginjal. Namun, tidak semua penderita GGK stadium akhir dapat dilakukan transplatasi, di samping, kadangkadang, sangat sulit untuk mendapatkan donor 
Terakreditasi Dirjen Dikti SK No. 56/DIKTI/Kep/2005

juga masih kontroversinya mengenai transplatasi organ tubuh manusia itu sendiri.

Dan hemodialisis menjadi pilihan akhir yang menjadi keharusan untuk dapat mempertahankan kehidupan pasien, sehingga pada akhirnya hemodialisis menjadi rutinitas bagi pasien sampai akhir hayat, karena penyakit ini tergolong tidak bisa disembuhkan. Dengan demikian hemodialisis (Sumpena, 2002:1) merupakan tindakan kedokteran yang memungkinkan seseorang dapat bertahan hidup meskipun ke dua ginjal sudah tidak berfungsi lagi karena suatu penyakit, sehingga, dapat dikatakan bahwa hemodialisis dapat menggantikan fungsi ginjal seseorang untuk tetap dapat bertahan hidup meskipun tidak sesempurna bila ginjal masih berfungsi, karena tidak semua fungsi ginjal dapat digantikan dengan hemodialisis.

Pengobatan atau perawatan terhadap penderita gagal ginjal yang menjalani terapi hemodialisis akan sangat berbeda bila dibanding dengan penyakit lain. Perawatan pada seseorang yang memiliki penyakit gagal ginjal kronik merupakan tantangan bagi tenaga perawat, sebab mereka tidak hanya menghendaki intervensi medis untuk memulihkan fungsi fisiknya, akan tetapi mereka juga menghendaki perawat yang sensitif terhadap kebutuhan yang diinginkan, termasuk menjadi konselor dalam melaksanakan program pengobatan. Oleh karena itu, perawat sejak awal dapat berperan dalam meminimalisasi perubahan potensial pada sistem tubuh pasien.

Penerapan komunikasi dalam pelayanan kesehatan mempunyai peran yang besar terhadap kemajuan kesehatan pasien. Komunikasi akan meningkatkan hubungan interpersonal dengan klien, sehingga akan tercipta suasana yang kondusif di mana klien dapat mengungkapkan perasaan dan harapan-harapannya. Kondisi saling percaya yang dibangun di antara perawat dan pasien, tentunya, akan mempermudah pelaksanaan dan keberhasilan program pengobatan.

Komunikasi antarbudaya adalah komunikasi yang dilakukan di antara orang-orang yang berbeda secara budaya. Oleh karena itu, komunikasi antarbudaya tidak hanya terjadi antara orang-orang yang berbeda bangsa, ras, etnik, bahasa, dan agama, namun terjadi di antara orang-orang yang berbeda tingkat pendidikan, status sosial, jenis kelamin, bahkan di antara profesi perawat dan pasien. Komunikasi di antara perawat dan pasien yang berbeda budaya tersebut dikenal juga dengan komunikasi terapeutik, yaitu kemampuan atau keterampilan perawat untuk membantu pasien beradaptasi terhadap stres, mengatasi gangguan psikologis, dan belajar bagaimana berhubungan dengan orang lain.

Pasien gagal ginjal akan melakukan hemodialisis (cuci darah) selama 4 jam, dan secara rutin dilakukan 2 (dua) kali dalam satu minggu. Dengan adanya keteraturan jadwal dan juga lamanya perawatan di rumah sakit pada saat hemodialisis, maka proses komunikasi antarbudaya di antara dokter/perawat dengan pasien gagal ginjal akan berbeda dengan dokter/ perawat dengan pasien yang berpenyakit biasa. Bagi para penderita penyakit yang berat, apalagi tidak bisa disembuhkan, komunikasi sangat penting untuk mempersiapkan pasien secara psikologis, dan bila mungkin secara spiritual, untuk yang sedang menghadapi ajalnya yang sudah "mengintip" di depan pintu di rumah sakit tersebut.

Dengan demikian, konteks komunikasi antara perawat dengan pasien gagal ginjal yang melakukan hemodialisis dari aspek verbal dan nonverbal tidak jarang turut menentukan proses perawatan pasien dalam hemodialisis. Oleh karena itu menarik untuk mengkaji lebih dalam mengenai:

(1) Bagaimana bahasa verbal yang digunakan oleh para perawat dalam proses hemodialisis penderita gagal ginjal?

(2) Bagaimana bahasa nonverbal yang ditampilkan para perawat dalam proses hemodialisis penderita gagal ginjal?

\subsection{Tujuan}

Penelitian dilakukan dengan tujuan untuk memeroleh gambaran atau memahami mengenai pola komunikasi terapeutik melalui perilaku verbal dan nonverbal yang dilakukan para perawat terhadap pasien penderita gagal ginjal kronik dalam proses hemodialisis (cuci darah) di rumah sakit. 


\subsection{Metodologi}

Penelitian ini menggunakan pendekatan yang objektif, yaitu penelitian yang bernuansa kuantitatif. Namun, data digali secara kualitatif, dan sebagai konsekuensinya data yang dianalisis dalam penelitian ini seluruhnya berupa data kualitatif. Selanjutnya, pemaparan mengenai analisis data dilakukan secara deskriptif, yaitu memaparkan atau menjelaskan situasi atau peristiwa dengan jalan mendeskripsikan atau melukiskan secara sistematis, faktual, dan akurat mengenai fakta-fakta, sifat-sifat dari fenomena yang diselidiki. Dengan demikian, penelitian ini tidak menguji hipotesis.

Teknik pengumpulan data dalam penelitian ini dilakukan melalui:

(a) Observasi partisipatif, yaitu penulis melihat langsung cara perawat melakukan komunikasi dengan pasien.

(b) Wawancara formal, yaitu wawancara mendalam yang dilakukan dengan mengajukan pertanyaan-pertanyaan secara terstruktur. Wawancara formal ini dilakukan kepada 1 (satu) orang perawat untuk masing-masing rumah sakit yang menjadi objek penelitian.

(c) Wawancara informal dan tidak terstruktur, dilakukan kepada salah satu pasien gagal ginjal dan juga salah satu keluarga pasien gagal ginjal untuk mendapat informasi tambahan mengenai komunikasi yang dilakukan perawat.

(d) Studi kepustakaan yang dilakukan oleh penulis tidak hanya dengan jalan memanfaatkan buku, tetapi juga dilakukan dengan mencari informasi dari surat kabar, majalah, internet dan sumber bacaan lain.

Analisis Data. Dari penggalian data di lapangan, penulis melakukan akumulasi data, kemudian memadukan dan membuat klasifikasi dari data tersebut. Pada gilirannya, analisis yang dilakukan adalah mendeskripsikan proses komunikasi perawat dengan pasien gagal ginjal menjadi uraian atau penjelasan yang sistematis.

\subsection{Objek Penelitian}

Penelitian ini mengambil objek di tiga Rumah Sakit yang berbeda yang memiliki unit hemodialisis
(Cuci darah) yaitu Rumah Sakit Pemerintah dalam hal ini adalah RSU.Hasan Sadikin, Rumah sakit khusus Ginjal yaitu RS.Ny.R.A.Habibie, dan Rumah Sakit bernuansa Agama dalam hal ini diwakili oleh RS Al Islam Bandung.

\section{Tinjauan Kepustakaan}

\subsection{Pemahaman terhadap Komunikasi}

Sepanjang rentang daur kehidupannya, manusia sesungguhnya melakukan komunikasi dari mulai manusia itu masih di rahim ibunya, lalu dilahirkan sampai dengan menjelang meninggal atau kematiannya. Karena itu, komunikasi tidak bisa dipisahkan dari setiap individu yang hidup. Komunikasi juga merupakan hal yang sangat penting bagi individu dalam melakukan interaksi. Komunikasi adalah proses saling memahami yang dilakukan oleh para peserta komunikasi melalui transaksi makna. Gorden (dalam Mulyana, 2007:76) menjelaskan bahwa komunikasi secara ringkas dapat didefinisikan sebagai suatu transaksi dinamis yang melibatkan gagasan dan perasaan. Sementara itu, Rosengren (dalam Mulyana, 2007:76) berpendapat bahwa komunikasi merupakan interaksi subjektif purposif melalui bahasa manusia yang berartikulasi ganda berdasarkan simbol-simbol.

Komunikasi pada gilirannya akan melibatkan proses pemaknaan terhadap bahasa verbal dan bahasa nonverbal. Bahasa verbal adalah seperangkat simbol, dengan aturan untuk mengombinasikan simbol-simbol tersebut yang digunakan dan dipahami suatu komunitas. Komunikasi verbal adalah komunikasi tatap muka, atau berbicara satu sama lain, dengan relasi dua arah. Artinya, terjadi semacam diskusi tentang sesuatu di mana kedua belah pihak saling memberikan perhatian dan mendengar secara aktif satu sama lain.

"Pesan-pesan verbal tidak hanya meliputi bagaimana kita berbicara dengan orang lain, namun juga kegiatan internal-internal berpikir dan pengembangan makna kata-kata yang digunakan. Proses-proses ini (bahasa-bahasa verbal dan pola berpikir) secara vital berhubungan dengan 
Terakreditasi Dirjen Dikti SK No. 56/DIKTI/Kep/2005

persepsi dan pemberian serta pernyataan makna" (Mulyana, 2005: 30)

Dengan demikian, bahasa merupakan alat utama yang digunakan dalam sebuah proses komunikasi. Bahasa menjadi alat dalam menyampaikan pola pikir seseorang, pada gilirannya bahasa juga akan menjadi penanda dari pola pikir itu sendiri, karena sistem linguistik (tata bahasa) dari suatu bahasa bukan sekadar alat penyampai gagasan, tetapi sebagai pembentuk gagasan dan pemandu aktivitas manusia. Oleh karena itu, bahasa adalah budaya. Bahasa akan berkaitan langsung dengan bagaimana cara-cara kita berpikir. Karena kultur yang berbeda maka memiliki bahasa yang berbeda dan pandangan hidup yang berbeda, sehingga mereka memiliki keyakinan dan nilai-nilai yang berbeda pula.

Sebagai sebuah penanda realitas, bahasa mepunyai fungsi untuk penamaan (naming atau labeling), sebagai sarana untuk berhubungan dengan orang lain, dan memungkinkan kita saling memahami mengenai diri, kepercayaankepercayaan, dan tujuan-tujuan. Namun, bahasa verbal memiliki berbagai keterbatasan (Mulyana,2007:269-279), yaitu;

(1) Keterbatasan jumlah kata yang tersedia untuk mewakili objek

(2) Kata-kata bersifat ambigu dan kontektual

(3) Kata-kata mengandung bias budaya

(4) Pencampuradukan fakta, penafsiran, dan penilaian.

Dengan berbagai keterbatasan yang dipunyai oleh bahasa verbal, maka komunikasi akan efektif bila melibatkan bahasa nonverbal. Kita memang mempersepsi manusia tidak hanya lewat pesan verbal, tetapi juga lewat bahasa nonverbalnya. Albert Mehrabian (dalam Mulyana,2007:351) menyatakan bahwa $93 \%$ dari semua makna sosial dalam komunikasi tatap muka diperoleh dari isyaratisyarat nonverbal. Dengan demikian, bahasa non verbal, menurut Samovar dan Porter (dlm Mulyana,2007;343), adalah mencakup semua rangsangan (kecuali rangsangan verbal) dalam seting komunikasi. Beberapa pesan nonverbal tersebut adalah:

(1) Bahasa Tubuh
Semua anggota tubuh para perawat dalam proses hemodialisis dapat menjadi simbol bagi pesan dalam proses komunikasi, seperti wajah (termasuk senyuman dan pandangan mata), tangan, kepala, kaki, dan bahkan tubuh secara keseluruhan.

(2) Sentuhan

Sentuhan sesorang akan memberikan makna yang berbeda tergantung pada konteks komunikasi yang dilakukan juga tergantung budaya yang menjadi latar belakangnya. Nilai berkomunikasi melalui sentuhan dianggap sangat penting dalam komunikasi antarmanusia, seperti halnya antara dokter dan pasien.

(3) Parabahasa

Parabahasa atau vokalic adalah aspek dari suara selain ucapan yang meliputi kecepatan berbicara, nada suara (tinggi/rendah), intensitas (volume) suara, intonasi, kualitas vokal (kejelasan), warna suara, dsb. Parabahasa ini akan memberikan simbol tentang perasaan yang akan memengaruhi komunikasi di antara perawat dan pasien.

(4) Penampilan Fisik (Busana)

Dokter berjas putih dan perawat juga berseragam putih menjadi ciri khas para petugas kesehatan. Setiap orang memang punya persepsi mengenai penampilan fisik, baik busananya dan juga ornamen lain yang dipakainya. Kita memang cenderung mempersepsi dan memperlakukan seseorang dengan cara berbeda bila ia mengenakan pakaian berbeda. Bahkan, sebagian orang berpandangan bahwa pilihan atas busana mencerminkan kepribadian.

(5) Proksemik

Bahasa nonverbal yang menyangkut orientasi ruang dan jarak pribadi. Setiap budaya punya cara khas dalam mengkonseptualisasikan ruang dan jarak pribadi dalam komunikasi

(6) Konsep Waktu

Waktu menentukan hubungan antarmanusia. Pola hidup manusia dalam waktu dipengaruhi oleh budayanya. Waktu berhubungan erat dengan perasaan hati dan perasaan-perasaan 
manusia. Kronemika adalah studi dan interpretasi atas waktu sebagai pesan. Bagaimana orang mempersepsi waktu dan memperlakukan waktu secara simbolik menunjukkan jati diri seseorang.

\subsection{Komunikasi Terapeutik}

Berbagai upaya pengobatan dilakukan untuk mengembalikan kondisi ke keadaan semula agar menjadi sehat kembali. Banyak paket pengobatan yang ditawarkan untuk menjadi sehat tergantung pada keyakinan terhadap penyakit dan cara-cara pengobatannya. Menurut Samovar, terdapat tiga pemahaman/konsepsi yang berbeda terhadap 'sakit' yang pada gilirannya menyebabkan perbedaan dalam upaya pengobatannya, yaitu:

(a) Biomedical Sistem

Biomedical system adalah sistem kepercayaan mengenai sakit yang memusatkan perhatian pada hasil diagnosis dan penjelasan yang ilmiah. Pada pendekatan ini, sakit akan berkenaan dengan isu medis, penyakit adalah hasil dari kelainan struktur atau fungsi badan. Agen seperti bakteri dan virus, atau suatu kondisi badan seperti suatu luka-luka, secara umum menjadi penyebab sakit. Dengan demikian, pengobatan melalui penghancuran atau pemindahan (seperti melalui operasi) terhadap agen yang menjadi menyebab merupakan senjata yang ampuh untuk mengembalikan kesehatan.

(b) Personalistic System

Dalam sistem yang personalistik, penyakit adalah hasil dari intervensi aktif oleh suatu hal-hal yang gaib (dewa, hantu, atau roh jahat), atau yang dibuat oleh manusia (sihir atau santet). Orang yang sakit adalah korban dari hukuman atau disumbang penyakit oleh seseorang. Pada sistem yang personalistik sebagai pemahaman terhadap sakit, maka penyembuhan dilakukan melalui jalur nonmedis, yaitu upaya-upaya untuk menghilangkan pengaruh gaib tersebut, sehingga pengobatan dilakukan dengan jalan sesuatu yang gaib kembali seperti ruwatan, sesajen, atau melalui dukun dan sebagainya

\section{(c) Naturalistic System}

Pendekatan yang naturalistik cenderung melihat sakit dengan menjelaskan keseimbangan dari unsur-unsur yang ada pada badan manusia. Dalam sistem ini, penyakit diakibatkan oleh ketidakseimbangan antara unsur-unsur yang ada pada diri manusia. Menurut pandangan ini, dalam diri manusia terdapat unsur dingin dan panas, yang akan menjadi agen bagi penyakit bila kedua unsur ini tidak seimbang. Makanan menjadi agen yang memengaruhi ketidakseimbangan unsur panas dan dingin dalam tubuh manusia. Upaya penyembuhan yang dilakukan dalam pendekatan ini adalah melalui usaha untuk menyeimbangkan unsur-unsur panas dan dingin tersebut. Contohnya, melalui pengobatan herbal.

Dengan adanya perbedaan terhadap konsep 'sakit', melahirkan upaya-upaya pengobatan yang berbeda. Sebagai konsekuensi adanya perbedaan ini, maka dalam kehidupan seharai-hari kita mengenal pengobatan medis melalui dokter dengan pengobatan alternatif melalui dukun, tabib, sinshe, atau orang pintar, dsb. Sudah barang tentu hal itu akan menjadikan perbedaan perilaku yang ditampilkan oleh masing-masing sebagai akibat adanya berbedaan budaya dari dua cara-cara pengobatan tersebut.

Dalam kehidupan sehari-hari, kita tidak bisa lepas dari komunikasi. Kenyataannya memang komunikasi secara mutlak merupakan bagian integral dari kehidupan kita, tidak terkecuali seseorang berstatus dokter atau perawat yang tugasnya sehari-hari selalu berhubungan dengan orang lain. Pasien selalu menuntut pelayanan pengobatan yang paripurna, sakit yang diderita bukan hanya sakit secara fisik, namun psiko (jiwanya) juga, terutama mengalami gangguan emosi.

Kepuasan pasien pada akhirnya bisa tercapai apabila pelayanan yang diberikan sesuai dengan ekspektasi harapan konsumen. Di antaranya, faktor-faktor pendukung kepuasan konsumen adalah ketepatan waktu, kenyamanan tempat, serta keramahan. Situasi ruangan bisa disesuaikan dengan pasien. Dengan demikian keterampilan 
komunikasi dan empati merupakan dasar yang kuat dalam menjalankan etika dalam perawatan pasien yang mencakup beberapa hal, yaitu:

(1) Kesanggupan memahami keluhan dan pribadi pasien.

(2) Kemampuan menumbuhkan empati.

(3) Kemampuan mempertahankan kerahasiaan hubungan dokter-pasien.

(4) Kewajiban melakukan pendekatan ilmiah (analitik) pada pasien dan masalahnya.

(5) Kewajiban memberitahu pasien tentang tindakan dan rencana selanjutnya, serta melanjutkan asuhan pasien.

(6) Kemampuan menolong pasien mengambil keputusan terbaik mengenai penyakit dan hidupnya (Djauzi, www.dharmais.co.id).

Untuk itu, dalam hal perawatan pasien, dikenal dengan istilah terapeutik atau komunikasi terapeutik. Northouse (dalam Suryani,2005:12) menjelaskan bahwa komunikasi terapeutik itu adalah kemampuan atau keterampilan perawat untuk membantu pasien beradaptasi terhadap stres, mengatasi gangguan psikologis dan belajar bagaimaa berhubungan dengan orang lain.

Dengan demikian, tujuan dari komunikasi terapeutik adalah untuk mengembangkan pribadi klien ke arah yang lebih positif atau adaptif dan diarahkan pada pertumbuhan pasien yang meliputi:

(1) Penerimaan diri dari pasien terhadap penyakit, sehingga pasien bisa menghargai dan menerima dirinya dengan penyakit yang ada dalam tubuhnya.

(2) Kemampuan membina hubungan interpersonal yang tidak superfisial dan saling bergantung dengan orang lain.

(3) Adanya tujuan yang realistik pada diri pasien untuk kehidupan ke depannya, serta meningkatkan kemampuan pasien untuk memenuhi kebutuhan dirinya.

Oleh karenanya dalam melaksanakan komunikasi terapeutik terdapat beberapa prinsip dasar yang harus dipahami dalam membangun dan mempertahankan hubungan yang terapeutik tersebut, yaitu:

(1) Hubungan perawat dengan pasien adalah hubungan yang saling menguntungkan, sehingga kualitas hubungan ditentukan oleh bagaimana perawat mendefinisikan dirinya sebagai manusia.

(2) Perawat harus menghargai keunikan pasien. Tiap individu mempunyai karakter yang berbeda-beda. Karena itu, perawat perlu memahami perasaan dan perilaku pasien dengan melihat perbedaan latar belakang keluarga, budaya, dan keunikan setiap individu.

(3) Komunikasi yang dilakukan harus dapat menjaga harga diri pemberi maupun penerima pesan. Dalam hal ini, perawat harus mampu menjaga harga dirinya dan harga diri pasien.

(4) Komunikasi yang menciptakan tumbuhnya hubungan saling percaya (trust) harus dicapai terlebih dahulu sebelum menggali permasalahan dalam memberikan alternatif pemecahan masalah (Suryani, 2005:15).

\section{Pembahasan Hasil Penelitian}

Dalam metode penelitian ini, berbagai pertanyaan yang muncul dalam penelitian ini dicari jawabannya melalui studi deskriptif dengan data kualitatif. Peneliti mencoba melakukan akumulasi data, kemudian mendeskripsikan proses komunikasinya, sehingga menjadi uraian penjelasan yang sistematis. Data yang diperoleh dari hasil penelusuran, dicoba untuk dipilah-pilah data berdasarkan tema-tema tertentu. Apa yang diamati, dikonfirmasi dengan hasil wawancara.

Secara akumulatif, penelitian dilakukan dalam kurun waktu kurang lebih 3 (tiga) minggu. Penelitian dilakukan dengan menggunakan studi dokumen, yakni mengkaji dokumen yang berkenaan dengan penelitian dan wawancara mendalam dengan mengunakan pola wawancara tidak berstruktur - kepada beberapa informan atau narasumber yang dipilih atas pertimbangan bahwa mereka adalah orang-orang yang berkompeten dalam masalah penelitian juga observasi pada ruang kerja pengobatan. Beberapa informan itu adalah:

(1) Diah Herawati, Kepala Perawat Bagian Hemodialisis di RSU Hasan Sadikin. 
Wawancara dilakukan pada Selasa, 16 Januari 2007, pukul 09.00, di ruang perawat Hemodialisa RSU Hasan Sadikin.

(2) Asep, yaitu perawat dan kepala pelatihan Hemodialisis di RS. Ny. R.A. Habibie. Wawancara dilakukan pada Rabu, 24 Januari 2007, pukul 09.00, di Ruang Hemodialisis RS.Ny R.A. Habibie.

(3) Sari, perawat yang bertugas di Rumah Sakit Al Islam Bandung,. Wawancara dilakukan pada Rabu, 17 Januari 2007, pukul 09.30, di RS Al Islam, Jl Soekerno Hatta, Bandung.

(4) Komar beserta Istri, pasien hemodialisis di RS Ny.RA. Habibie selama 3 tahun. Wawancara dilakukan pada Rabu, 31 Januari 2007, pukul 08.00 , pada saat ia sedang melakukan proses hemodialisis.

(5) Betty, keluarga pasien Hemodialisis selama 5 tahun (pasien sudah meninggal saat dilakukan wawancara). Wawancara dilakukan pada Sabtu, 19 Januari 2007, pukul 19.00, di rumah yang bersangkutan, Komp. Cipadung Indah.

Sebagaimana telah dibahas dalam kerangka teoretis bahwa komunikasi merupakan hal yang sangat penting bagi individu dalam melakukan interaksi. Komunikasi adalah proses saling memahami yang dilakukan oleh para peserta komunikasi melalui transaksi bermakna. Penerapan komunikasi dalam pelayanan kesehatan mempunyai peran yang besar terhadap kemajuan kesehatan pasien. Demikian pula komunikasi yang dilakukan oleh para petugas kesehatan dalam hal ini adalah perawat dengan pasien gagal ginjal dalam proses hemodialisis.

Dengan demikian, berdasarkan hasil wawancara dengan para informan di atas, maka peneliti akan memetakan secara kualitatifmengenai pola komunikasi yang dilakukan perawat dalam proses hemodialisis dari aspek verbal yang menyangkut mengenai bahasa dan dalam kaitannya dengan komunikasi konteks rendah dan komunikasi konteks tinggi. Sementara dari aspek bahasa non verbal peneliti akan memetakan secara kualitatif mengenai sentuhan, penampilan, pengaturan ruang dan jarak, serta konsep waktu.

\subsection{Bahasa Verbal dalam Komunikasi Perawat dan Pasien Gagal Ginjal}

Seorang pasien hemodialisis akan melakukan cuci darah minimal 2 kali dalam satu minggu dan akan berlangsung selama hidupnya. Dengan kata lain, hemodialisis akan dilakukan secara rutin oleh pasien yang dinyatakan gagal ginjal kronik. Hemodialisis yang dilakukan tidak menyembuhkan penyakit gagal ginjal kronik, akan tetapi dapat memperpanjang usia pasien, karena ginjal pasien sudah tidak berfungsi dan digantikan dengan ginjal buatan (mesin). Pada saat melakukan hemodialisis, pasien akan dicuci ginjalnya selama 3 sampai 4 jam.

Sebagai penyakit yang sudah tidak dapat disembuhkan, maka pada tahap awal sebelum hemodialisis dilakukan, pasien perlu memeroleh informasi yang lengkap pengenai penyakit gagal ginjal dan konsekuensi yang akan dilalui selama hidupnya. Proses penyampaian informasi mengenai penyakit gagal ginjal dan konsekuensi yang ditanggung pasien, seperti dijelaskan oleh Diah berikut ini:

"Untuk pasien yang sudah dinyatakan positif gagal ginjal kronik, hanya ada dua jalan yang dapat dilakukan, yaitu transplantasi ginjal atau hemodialisis (cuci darah). Hanya hemodialisis seringkali menjadi pilihan orang-orang untuk melanjutkan atau bertahan hidup karena transplantasi ginjal di samping biaya yang mahal, donor ginjal yang sulit, juga masih kontroversinya mengenai cangkok ginjal ini. Oleh karena itu, dalam perawatan pasien, hemodialisis melibatkan berbagai pihak; yaitu ahli ginjal, perawat yang akan seterusnya melakukan hemodialisa, ahli gizi, dan ahli jantung. Pada tahap awal, pasien akan diberikan penjelasan secara komprehensifmengenai semua konsekuensi dari penyakit gagal ginjal ini. Namun, kalaupun ada yang masih belum lengkap, pasien dan juga keluarganya seringkali menanyakan kepada perawat mengenai segala ihwal tentang kehidupan selanjutnya pasien" (wawancara dengan Diah).

Sejalan dengan penjelasan di atas, Sari seorang perawat hemodialisis di RS Al-Islam 
Terakreditasi Dirjen Dikti SK No. 56/DIKTI/Kep/2005

menyatakan, sebagai berikut:

"Pada awalnya, pasien akan mengunjungi dokter ahli ginjal untuk memeriksakan keluhan yang dirasakan pada bagian pinggang, berdasarkan hasil diagnosis dan keterangan dari laboratorium, maka pasien akan dinyatakan gagal ginjal bila kreatinin yang terkandung dalam darah melebihi ambang batas normal. Setelah dinyatakan terkena gagal ginjal, maka pasien memerlukan hemodialisis dan akan dirujuk ke rumah sakit yang memiliki fasilitas hemodialisis. Dokter yang ada di rumah sakit rujukan akan memeriksa ulang secara komprehensif. Dari hasil pemeriksaan ini, dokter akan menentukan kadar hemodialisis yang harus dilalui pasien. Yang terpenting dalam tahap awal ini adalah penjelasan mengenai konsekuensi yang harus ditanggung oleh pasien gagal ginjal selama hidupnya. Penjelasan dilakukan biasanya oleh dokter, tetapi juga seringkali melibatkan perawat karena kesibukan dokter itu sendiri. Penjelasan biasanya berkisar mengenai hemodialisis yang harus dilalui sebanyak 2 kali dalam satu minggu, pelaksanaan yang harus rutin agar pasien bisa bertahan lebih lama, pantangan yang harus dituruti, obat-obatan yang perlu dikonsumsi, bahkan termasuk bagaimana peranan keluarga bagi pasien" (wawancara dengan $\mathrm{S}$ ).

Responden berikutnya adalah Asep yang menjadi kepala perawat di RS. Ny. R.A. Habibie, yaitu rumah sakit khusus untuk ginjal dan proses hemodialisis menjelaskan sebagai berikut:

"Pasien gagal ginjal kronik seringkali tidak bisa menerima bahwa dirinya harus menjalani hemodialisis dan menjadi tidak berdaya, baik secara fisik maupun secara mental, karena yang asalnya aktif dengan segala kegiatannya dan juga mandiri menjadi orang yang akan dibatasi gerakannya oleh jadwal dan penyakitnya serta menjadi tergantung akan bantuan orang lain. Oleh karena itu, sering kali penderita GGK pada awalnya menjadi tress dan mengalami masa "denail" (penyesuaian), bahkan sampai 2 tahun. Dokter bersama perawat biasanya akan menjelaskan secara komprehensif mengenai ihwal GGK dan konsekuensi yang akan dijalani pasien. Hal ini dilakukan agar pasien mengerti bagaimana bertahan hidup dengan GGK, dan kalau ada apa-apa perawat tidak disalahkan" (wawancara dengan Asep).

Dari uraian yang dikemukakan, maka ketiganya sepakat bahwa tahap awal proses perawatan pasien hemodialisis adalah menyampaikan mengenai konsekuensi yang akan dilalui dari penyakit gagal ginjal seperti proses hemodialisis yang akan dilalui sepanjang hidupnya, larangan yang harus diikuti setelah menjadi pasien hemodialisis. Dengan demikian, dalam hal proses hemodialisis komunikasi yang dilakukan antara dokter, perawat, dan pasien, termasuk dalam "komunikasi konteks rendah," yaitu mengatakan apa yang dimaksud dan memaksudkan apa yang dikatakan.

Keterusterangan dari perawat dan dokter yang menangani pasien GGK, diakui pula oleh Betty sebagai keluarga pasien, seperti dinyatakan berikut ini:

"Ketika ayah saya harus menjalani cuci darah pada hari pertama di RS. Ny. R.A. Habibie, kami diberi penjelasan yang panjang lebar mengenai apa itu gagal ginjal dan konsekuensi hidup selanjutnya. Orang yang gagak ginjal kronik akan dapat bertahan hidup sampai panjang usia, perawat mencontohkan pasien gagal ginjal yang sudah melakukan hemodialisis selama 18 tahun dan saat ini masih bisa beraktivitas, dan kami akhirnya bisa bertemu karena pasien tersebut melakukan hemodialisis di RS yang sama. Di samping itu, perawat juga menjelaskan dari segi larangan dan juga gizi yang harus dipenuhi penderita GGK. Dengan penjelaan itu, alhamdulillah, ayah saya bisa bertahan sampai 5 tahun. Beliau meninggal karena penyakit hipertensinya dan bukan oleh gagal ginjalnya" (wawancara-Betty).

Dalam komunikasi disebutkan bahwa ada tiga hal penting yang harus ditunjukkan oleh pelaku kesehatan, mulai dari dokter, perawat, dan berbagai profesi kesehatan lainnya ketika berkomunikasi dengan pasien, yaitu perhatian (attention), empati (empathy), dan kepedulian (care). Pelaku kesehatan haruslah menghindari memiliki sifat arogan, dan merasa dirinya lebih penting. Sebaliknya, petugas kesehatan perlu menata komunikasi. Hal ini penting untuk memecahkan ketidakseimbangan informasi yang terjadi. Pelayanan kesehatan seringkali menjadi tidak efektif hanya karena ada perbedaan latar belakang dan pengetahuan pasien dan dokter, sehingga 
berakibat adanya ketidakseimbangan informasi. Komunikasi melalui keramahtamahan merupakan hal yang sangat utama dalam pelayanan kesehatan. Dalam bahasa Inggris, keramahtamahan itu adalah 'hospitality', suatu istilah yang erat kaitannya dengan rumah sakit (hospital), adalah suatu impian dari masyarakat untuk mendapatkan pelayanan yang ramah dari pelaku kesehatan.

Penerapan komunikasi terapeutik dalam pelayanan perawatan mempunyai peran yang besar terhadap peningkatan pengetahuan pasien terhadap penyakit. Interaksi perawat dengan pasien memfasilitasi proses transfer pengetahuan maupun informasi tambahan yang belum dimengerti oleh pasien. Diskusi yang dilakukan berorientasi pada pemahaman pasien terhadap proses penyakitnya. Dengan adanya pemahaman pasien, diharapkan pasien akan kolaboratif dan patuh dalam menjalankan program pengobatan.

Selanjutnya, Kosa dan Robertson (1995) menjelaskan bahwa perilaku pasien mengenai kesehatan dirinya untuk mencari informasi, sebetulnya dimotivasi oleh kebutuhan psikologi individu untuk mengurangi kekhawatiran yang disebabkan oleh adanya ancaman dari suatu penyakit, yaitu: (1) penilaian tentang suatu gangguan kesehatan; (2) peningkatan rasa khawatir karena persepsi tentang gejala penyakit; (3) penerapan pengetahuan sendiri terhadap kesehatan; dan (4) bentuk tindakan untuk menghilangkan kekhawatiran dan gangguan kesehatan tersebut. (http://www.mail-archive.com/ dokter@yahoogroups.com)

\subsection{Bahasa Nonverbal dalam Komunikasi Perawat dan Pasien Gagal Ginjal}

Proses komunikasi terapeutik yang dilakukan dalam rangka perawatan pasien tidak hanya melibatkan bahasa verbal saja, akan tetapi juga melibatkan bahasa nonverbal seperti gerakan tubuh, sentuhan, pakaian, jarak komunikasi, dan konsep waktu. Dalam rangka perawatan pasien gagal ginjal kronik melalui hemodialisis bahasa nonverbal yang turut memengaruhi komunikasi terapeutik adalah: bahasa tuhuh, sentuhan, parabahasa, penampilan fisik, proksemik, konsep waktu, dan artefak.

\section{(1) Bahasa Tubuh}

Bahasa tubuh dari para perawat dalam proses hemodialisis dapat menjadi simbol dalam proses komunikasi terapeutik seperti wajah (termasuk senyuman dan pandangan mata), tangan, kepala, kaki, dan bahkan tubuh secara keseluruhan. Hal ini dikarenakan perawat harus hadir secara utuh (fisik dan psikologis) sewaktu berkomunikasi dengan klien. Perawat tidak cukup hanya mengetahui teknik komunikasi dan isi komunikasi, tetapi yang sangat penting adalah penampilan dalam berkomunikasi. Menghadirkan diri ini terdiri dari menghadirkan diri secara fisik dan secara psikologis seperti dikemukakan oleh para perawat berikut ini:

"Selama proses hemodialisis, perawat selalu hadir di sekitar pasien. Hal ini dilakukan karena pada saat hemodialisis seringkali terjadi hal-hal yang di luar perhitungan manusia, seperti tiba-tiba tekanan darah pasien turun, pusing-pusing, atau juga kendala pada mesin. Bahkan, tiba-tiba aliran listrik mati, sehingga hemodialisis harus manual" (wawancara dengan Diah).

"Pasien GGK biasanya tidak kentara secara fisik, apalagi pada masa-masa awal hemodialisis, sehingga sama seperti orang yang sehat saja. Oleh karena itu, pasien harus diperlakukan seperti orang yang sehat sekalipun pada jadwal tertentu dia melalukan hemodialisis. Oleh kerana itu, pada masa hemodialisis yang panjang (selama 3-4 jam), pasien seringkali ingin ditemani sekadar untuk 'ngobrol atau curhat'. Seringkali kami menjadi terlibat dalam pembicaraan di antara para pasien dan kami mencoba untuk menampilkan perilaku yang dapat diterima oleh pasien" (wawancara-Sari).

Kehadiran fisik perawat berarti kebersamaan perawat dalam berkomunikasi dengan klien, yaitu mendengar, mengamati, serta memberikan perhatian terhadap apa yang dikatakan dan bagaimana perilaku klien. Kehadiran fisik, yaitu perhatian yang diberikan melalui penampilan tubuh, hal ini penting dalam komunikasi interpersonal karena tubuh dapat memperkuat pesan yang disampaikan dalam bentuk kata-kata. 
Terakreditasi Dirjen Dikti SK No. 56/DIKTI/Kep/2005

"Dengan lamanya proses hemodialisis yang memakan waktu sampai 4 (empat) jam dan pasien tidak dapat meninggalkan tempat, maka tentunya pasien akan merasa tidak nyaman. Oleh karena itu, biasanya aktivitas pasien di samping tidur adalah bercerita baik dengan sesama pasien juga dengan perawat sambil melakukan pemeriksaan. Hal ini dikarenakan ruang perawat memang menyatu dengan ruang hemodialisis. Oleh karenanya pasien dapat segera menemukan kami bila terjadi sesuatu. Juga seringkali diajak ngobrol oleh mereka mengenai apa saja, dan tentunya kami menjadi pendengar yang baik saja. Kami, sesekali juga duduk di tempat tidur pasien" (wawancara dengan Asep).

Haber J. (1982) dalam (Suryani,2006 ;33) mengidentifikasi lima sikap atau cara untuk menghadirkan diri secara fisik. Pertama, berhadapan. Berhadapan artinya menghadap pasien dengan jujur dan terbuka, yaitu sikap tubuh dan wajah menghadap ke pasien. Kedua, mempertahankan kontak mata. Kontak mata menunjukkan bahwa perawat mendengar dan memperhatikan pasien. Ketiga, membungkuk ke arah pasien. Posisi ini akan menunjukkan keinginan untuk mengatakan atau mendengar sesuatu, Posisi ini juga menunjukkan bahwa perawat merespons dan perhatian terhadap pasien, dan menunjukkan keinginan untuk membantu pasien.

Keempat, mempertahankan sikap terbuka. Tidak melipat kaki atau tangan, tetapi mempertahankan posisi tangan di samping atau dalam posisi terbuka lainnya, menunjukkan keterbukaan. Kelima, tetap rileks. Menciptakan lingkungan yang rileks dan menjaga privasi klien dan rasa nyaman bagi klien sangat penting dalam membantu pasien untuk membuka diri. Perawat harus dapat mengontrol keseimbangan antara ketegangan dan relaksasi dalam berespons terhadap pasien. Jika perawat merasa tegang, maka klien akan ikut tegang karena adanya transfer feelings dari perawat ke pasien.

Di samping kelima cara menghadirkan diri secara fisik tersebut di atas, perawat juga perlu memperhatikan cara menghadirkan diri secara psikologis. Kehadiran psikologis, yaitu mendengar secara aktif (active listening) yang berarti mendengar dengan telinga, pikiran, dan perasaan perawat, tentang apa yang diucapkan atau disampaikan klien dengan kata-kata dan apa yang diisyaratkan klien lewat nonverbalnya. Selama mendengar aktif, perawat mengikuti apa yang dibicarakan klien dan memperhatikan perilaku klien serta memberikan tanggapan yang tepat. Menjadi pendengar yang baik merupakan keterampilan dasar dalam melakukan hubungan perawat-klien. Ellis, Gates, and Kenworthy (dalam Suryani,2006;49) menjelaskan bahwa mendengarkan orang lain dengan penuh perhatian akan menunjukkan pada orang tersebut bahwa apa yang dikatakannya merupakan hal yang penting dan dia adalah orang yang berarti. Mendengarkan juga menunjukkan pesan "Anda bernilai untuk saya" dan "saya tertarik untuk mendengarkan Anda."

\section{(2) Sentuhan}

Sentuhan dari sesorang akan memberikan makna yang berbeda, tergantung pada konteks komunikasi yang dilakukan, juga tergantung budaya yang menjadi latar belakangnya. Nilai berkomunikasi melalui sentuhan, dianggap sangat penting dalam komunikasi antarmanusia, seperti halnya antara dokter, perawat, dan pasien.

Dalam perawatan pasien hemodialisis, perawat seringkali menggunakan sentuhan seperti halnya dijelaskan oleh tiga perawat hemodialisis berikut ini:

"Ketika proses hemodialisis berlangsung, seringkali pasien meminta kepada perawat untuk dipijat tangan atau kakinya karena pegal. Demikian pula ketika selesai hemodialisis, perawat harus memegang tangan dan menekan lukanya di mana terdapat bekas tusukan jarus suntik untuk menghentikan pendarahan" (wawancara dengan Asep).

"Sebelum melakukan hemodialisis, perawat perlu memeriksa tekanan darah pasien. Kemudian, ketika hemodialisis berlangsung, perawat juga memeriksa tekanan darah kembali, dan setelah berakhir hemodialisis perawat akan menekan tangan bekas jarum suntik agar darah bisa cepat berhenti" (wawancara - Diah).

"Sebagai perawat hemodialisis, saya sering memegang tangan dan kaki pasien GGK, dan saya 
tidak canggung, karena ini tuntutan pekerjaan, apalagi hemodialisis tidak membagi secara khusus mengenai pasien perempuan atau laki-laki. Bahkan, seringkali pasien meminta saya untuk memijat kakinya karena pegal apalagi yang belum melakukan operasi pembesaran pembuluh darah (apesant)" (wawancara-Sari).

Melihat pada sentuhan yang dilakukan oleh para perawat dalam proses hemodialisis, maka sentuhan dilakukan pada tiga periode, yaitu sebelum dilakukan hemodialisis, pada waktu berlangsung hemodialisis, dan setelah dilakukan hemodialisis. Sentuhan yang dilakukan termasuk pada kategori fungsional profesional, yaitu sentuhan yang bersifat dingin dan berorientasi pada tanggung jawab pekerjaan atau bisnis; dan sentuhan persahabatan-kehangatan, yaitu sentuhan yang menunjukkan kehangatan dan keakraban. Sentuhan pada situasi seperti yang digambar lewat hasil wawancara tersebut mempunyai arti "'empati" dan juga menunjukkan arti "saya peduli"' (Stuart dalam Suryani, 200;49).

\section{(3) Parabahasa}

Parabahasa atau vokalic adalah aspek dari suara, selain ucapan, yang meliputi kecepatan berbicara, nada suara (tinggi/rendah), intensitas (volume) suara, intonasi, kualitas vokal (kejelasan), warna suara, dsb. Parabahasa ini akan memberikan simbol tentang perasaan yang akan memengaruhi komunikasi di antara perawat dan pasien. Bagaimana perawat menggunakan para bahasa dalam perawatan hemodialisis, dituturkan Sari berikut ini:

"Orang yang terkena GGK biasa terjadi perubahan dari sisi psikologis emosinya yang jadi pemarah, perasaan putus asa, maupun tidak menerima keadaan dirinya sebagai orang yang menderita GGK. Dengan kondisi ini, pasien seringkali dalam hemodialisis menjadi cepat marah, atau merajuk dengan berbagai keluhan, dan sebagainya. Kalau sudah begini, kami biasanya membujuk mereka akan menenangkan mereka dengan suara yang lembut dan memberikan arahan dari sisi keagamaan"(wawancara-S).

Mendukung penjelasan dari perawat Sari mengenai parabahasa yang dipergunakan para perawat dalam proses hemodialisis, dikemukakan oleh Betty sebagai keluarga pasien;

"Setelah ayah saya tahu dirinya menjadi penderita GGK, maka seiring perjalanan waktu, dia menjadi cepat marah, mudah tersinggung, dan sebagainya. Dalam proses hemodialisis, seringkali ayah mengeluh dan menumpahkan kekesalan terhadap kami dalam perawatan di rumah kepada perawat. Kalau sudah seperti ini, maka perawat akan memberikan pengertian kepada ayah saya secara lembut dari sisi agama" (wawancara dengan Betty).

Nada suara pembicara mempunyai dampak yang besar terhadap arti pesan yang dikirimkan, karena emosi seseorang dapat secara langsung memengaruhi nada suaranya. Perawat harus menyadari dan mengontrol emosinya ketika sedang berinteraksi dengan klien, karena maksud untuk menyampaikan perhatian yang tulus terhadap klien dapat terhalangi oleh nada suara perawat yang kurang simpatik (Stuart dan Sundeen, dalam Suryani, 2006;48).

\section{(4) Penampilan Fisik (Busana)}

Penampilan memegang peranan penting dalam pergaulan dan hubungan perawat dengan pasien, baik secara positif maupun negatif. $K$ e $s$ a $n$ pertama pada seseorang akan tercipta dari penampilan fisik atau busananya. Penampilan yang baik, atau sebaliknya, bermula dari cara bagaimana orang berpakaian karena ternyata dari pakaian ini mempunyai faktor yang berdampak besar bagi orang yang bertemu dengan kita untuk pertama kali.

Perawat di tiga rumah sakit yang mempunyai fasilitas hemodialisis dalam melaksanakan pekerjaannya menggunakan seragam seperti RSU. Hasan Sadikin berseragan putih dan dibungkus lagi dengan warna hijau. Sementara, di rumah di RS Al Islam, berseragam hijau, sama dengan di RS Ny. R.A. Habibie yang berseragam hijau pula.

Ada beberapa alasan mengapa perawat selalu menggunakan seragam alasan itu dikemukakan Diah, bahwa:

"Penggunaan seragam biasanya digunakan pada saat sedang proses hemodialisis, alasan penggunaan seragam ini di samping untuk menjaga kebersihan ruang hemodialisis juga untuk membedakan antara perawat dengan petugas-petugas lain yang ada di rumah sakit. Para perawat akan menanggalkan pakaian seragamnya manakala keluar dari ruang 
hemodialisis" (wawancara-Diah).

Hal ini diakui pula oleh Komar dan istri sebagai pasien hemodialisis RS Ny. R.A. Habibie. Dijelaskan bahwa:

"Perawat di sini menggunakan seragam berwarna hijau untuk membedakan dengan yang lain, sehingga kami keluarga pasien menjadi tahu mana perawat atau petugas service mesin, termasuk dokter. Dengan berpakaian seragam, kami menjadi cepat untuk segera memenggil orang yang berseragam hijau, karena itu pasti perawat bila terjadi apa-apa pada pasien" (wawancara-Komar dan Istri).

Penampilan seseorang merupakan salah satu hal utama yang diperhatikan selama komunikasi interpersonal. Bentuk fisik, cara berpakaian, dan berhias, menunjukkan kepribadian, status sosial, pekerjaan, agama, budaya, dan konsep diri (Forsyth, dalam Suryani, 2006;47). Perawat yang memperhatikan penampilan dirinya dapat menimbulkan citra diri yang positif dan sikap profesional yang positif. Penampilan fisik perawat memengaruhi persepsi klien terhadap pelayanan/asuhan keperawatan yang diterima, karena tiap klien mempunyai pandangan atau citra bagaimana seharusnya perawat berpenampilan (Antai-Otong, dalam Suryani,2006;47). Walaupun penampilan tidak sepenuhnya mencerminkan kemampuan, tetapi penampilan perawat dapat memengaruhinya dalam membina hubungan saling percaya dengan klien (Forsyth, 1993).

\section{(5) Proksemik}

Proksemik adalah bahasa nonverbal yang menyangkut orientasi ruang dan jarak pribadi. Setiap budaya punya cara khas dalam mengonseptualisasikan ruang dan jarak pribadi dalam komunikasi. Dalam proses hemodialisis, bagaimana jarak komunikasi yang dilakukan oleh perawat berdasarkan pengalaman dari keluarga pasien dan pasien sendiri, dikemukakan berikut ini:

"Dalam berinteraksi dengan pasien para perawat RS Ny. R.A. Habibie lebih menunjukkan kedekatan. Hal ini ditunjukkan dengan jarak ketika dia memberikan informasi atau memeriksa pasien. Bahkan, ketika menenangkan pasien yang gelisah atau mempunyai keluhan lain, seringkali perawat mendekati pasien sambil mengusap bagian kaki atau tangan sambil duduk di tempat tidur" (wawancara dengan istri dari Komar).

"Para perawat di RS Al-Islam menjadi akrab dengan pasien maupun dengan keluarganya. Hal ini juga berdampak pada jarak ketika dia berinteraksi dengan pasien maupun dengan keluarganya. Seringkali kami keluarga pasien bergandengan tangan bersama perawat ketika bercerita atau juga bagaimana perawat duduk di tempat tiduk pasien sambil memijat kaki pasien" (wawancara dengan Betty).

Jarak dalam berkomunikasi sangat penting diperhatikan oleh perawat, karena akan memengaruhi kelancaran komunikasi. Jarak yang terlalu jauh menyebabkan perawat sulit untuk berespons secara tepat, karena perawat tidak bisa melakukan active listening. Menurut Stuart G.W. (1998) dalam Suryani (2006;68), jarak untuk hubungan intim terapeutik adalah $0-45 \mathrm{~cm}$, sedangkan jarak pribadi adalah 45-120 cm. Berdasarkan pengalaman jarak yang paling nyaman bagi perawat dan klien dalam berinteraksi adalah antara 30-40 cm. Akan tetapi, pada pasien-pasien dengan perilaku kekerasan, jarak yang bisa digunakan adalah antara $100-120 \mathrm{~cm}$.

Selain jarak dalam proksemik yang memengaruhi penerimaan pesan dalam komunikasi adalah penataan ruangan. Ruang bagi perawatan hemodialisis berdasarkan hasil pengamatan peneliti di tiga rumah sakit penyelenggara hemodialisis, disesuaikan dengan ' pandangan terhadap penyakit gagal ginjal kronik" yang dianggap sebagai penyakit yang tidak dapat disembuhkan sebagai akibat tidak berfungsinya ginjal.

Bagaimana pemahaman atau pandangan perawat mengenai gagal ginjal kronik dipaparkan oleh para perawat sebagai berikut:

"GGK adalah tidak berfungsinya ginjal seseorang karena suatu penyakit. Untuk itu, fungsi ginjal digantikan oleh mesin yang disebut DIALYZER" (wawancara-Asep).

"Gagal ginjal kronik, kami menyebutnya GGK adalah ginjal yang sudah tidak dapat menjalankan fungsinya, sehingga memerlukan alat untuk dapat membersihkan darah (hemodialisis), yang ada dalam tubuh sebagai pengganti ginjal yang tidak berfungsi tadi" (wawancara-S). 
"GGK merupakan disfungsi (tidak berfungsinya) ginjal secara normal sehingga memerlukan alat untuk menggantikan fungsi tersebut pada tubuh manusia, yaitu melalui alat yang dinamakan DIALYZER" (wawancara-Diah).

Dengan konsep bahwa GGK adalah tidak berfungsinya ginjal yang sudah kronik dan pasien melakukan hemodialisis sampai mencapai ajalnya, maka ini yang melandasi mereka menempatkan ruang perawat bersatu dengan ruang hemodialisis. Hal ini disebabkan untuk memudahkan pemantauan terhadap pasien ketika melakukan hemodialisis sebagaimana dikemukakan Asep:
"Bagi pasien hemodialisis, ketika melakukan proses cuci darah sering kali mengalami berbagai macam gangguan seperti pusing, sehingga ingin muntah, tiba-tiba tekanan darah menurun drastis, atau mesin yang tiba-tiba terkena gangguan, dan banyak lagi. Untuk itu, perawat harus selalu ada di dalam ruang hemodialisis untuk memantau semua pasien yang sedang melakukan hemodialisis. Karena itu pula ruang perawat berada di dalam ruang hemodialisis itu sendiri (wawancara-Asep).

(6) Konsep waktu

Waktu menentukan hubungan antarmanusia. Pola hidup manusia dalam waktu dipengaruhi oleh

Tabel 1

Pola Komunikasi Terapeutik Hemodialisis

\begin{tabular}{|c|c|}
\hline $\begin{array}{l}\text { JENIS PESAN DALAM } \\
\text { KOMUNIKASI }\end{array}$ & HASIL PENELITIAN \\
\hline Bahasa verbal & $\begin{array}{l}\text { Lugas, ekslisit, terus terang dan menggunakan bahasa yang mudah dipahami } \\
\text { (tidak menggunakan istilah-istilah kedokteran) yang sulit dipahami oleh pasien } \\
\text { maupun keluarganya. Di samping itu, juga menggunakan bahasa yang lebih } \\
\text { religius. Untuk konsep ini, temasuk pada konsep komunikasi konteks rendah. }\end{array}$ \\
\hline Bahasa tubuh & $\begin{array}{l}\text { Kehadiran perawat menjadi pesan adanya kepedulian dan empati perawat } \\
\text { terhadap pasien. }\end{array}$ \\
\hline Sentuhan & $\begin{array}{l}\text { Sentuhan sering digunakan dalam perawatan hemodialisis, dan ada pada tataran } \\
\text { sentuhan profesional dan keakraban. }\end{array}$ \\
\hline Parabahasa & $\begin{array}{l}\text { Intonasi yang lembut sangat dituntut untuk perawat hemodialisis, karena yang } \\
\text { dihadapi adalah pasien yang seringkali mengalami ganggungan emosi sebagai } \\
\text { akibat ditimpanya GGK }\end{array}$ \\
\hline Pena mpilan fisik & $\begin{array}{l}\text { Perawat dicirikan dengan seragam yang berbeda dari yang lainnya untuk } \\
\text { membedakan, sehingga memudahkan pasien dalam mengenalinya. }\end{array}$ \\
\hline Proksemik & $\begin{array}{l}\text { Kedekatan baik ditandai dari jarak fisik dalam berkomunikasi maupun dari tata } \\
\text { ruang hemodialiais menjadi ciri bagi proses perawatan hemodialisis }\end{array}$ \\
\hline Konsep waktu & $\begin{array}{l}\text { Pembagian waktu yang tegas dan ketaatan pasien terhadap pembagian waktu } \\
\text { dalam proses hemodialisis menjadi ciri pula dalam perawatan hemodialisis. }\end{array}$ \\
\hline
\end{tabular}


budayanya. Waktu berhubungan erat dengan perasaan hati dan perasaan-perasaan manusia. Kronemika adalah studi dan interpretasi atas waktu sebagai pesan. Bagaimana orang mempersepsi waktu dan memperlakukan waktu secara simbolik, menunjukkan jati diri seseorang.

Pada tiga rumah sakit yang diteliti, ternyata terdapat perbedaan dalam pembagian jadwal hemodialisis, yaitu sebagai berikut: untuk RSU Hasan Sadikin, hemodialisis dilakukan dengan 2 (dua) jadwal, yaitu mulai jam 08.00-14.00 dan jam 12.00-16.00. Hal yang sama dilakukan di RS Ny. R.A. Habibie, dengan jadwal mulai jam 07.00-14.00 dan jam 12.00-16.00. Sementara itu, di RS Al-Islam jadwal hemodialisis terdapat 3 (tiga) kali, yaitu 07.00-11.00, jam 11.00-15.00, dan jam 15.00-19.00. Di ketiga rumah sakit ini, ternyata di luar jam tersebut ada yang dinamakan over time, yaitu jadwal di luar yang ditetapkan bagi keadaan darurat, termasuk hari Minggu. Dengan demikian, praktis jadwal kerja hemodialisis adalah 24 jam. Di samping jadwal jam setiap hari, pasien hemodialisis akan dibagi dalam kelompok hari, seperti dikemukakan oleh Diah sebagai berikut:

"Pasien melakukan hemodialisis setiap Senin Kamis, Selasa - Jumat, Rabu - Sabtu. Ini adalah jadwal hemodialisis yang dilakukan 2 (dua) kali dalam satu minggu. Sementara, bagi mereka yang melakukan hemodialisis 3 (tiga) kali dalam satu minggu, jadwalnya adalah Senin - Rabu - Jumat dan Selasa - Kamis - Sabtu. Untuk itu, biasanya setiap pasien akan selalu patuh mengikuti jadwal ini, karena setiap harinya akan padat, sehingga bila terlewat dia harus melakukan over time dengan biaya yang berbeda" (wawancara-Diah).

Dari pembagian jadwal mengenai perawatan hemodialisis ini menjelaskan bahwa waktu menjadi sangat penting bagi penderita GGK ini dan harus ditaati oleh setiap pasien. Dengan demikian, konsep waktu pada perawatan hemodialiais adalah "monokronik", yaitu mempersepsi waktu sebagai berjalan lurus dari masa silam ke masa depan dan memperlakukannya sebagai entitas yang nyata dan bisa di pilah-pilah, dihabiskan, dibuang, dihemat, dipinjam, dibagi, hilang atau bahkan dibunuh, sehingga waktu tidak pernah kembali.
Menyimak dari pembahasan yang telah dikemukakan sebelumnya mengenai bahasa verbal dan bahasa nonvebal dalam proses hemodialisis bagi pasien penderita gagal ginjal kronik(GGK), maka kita dapat membuat kesimpulan sebagaimana Tabel 1.

\section{Daftar Pustaka}

Baradero, Mary \& Mary Wilfrid \& Yakobus Siswadi. 2006. Konseling dalam Keperawatan. Jakarta: Penerbit Buku Kedokteran EGC.

Djauzi Samsuridjal, www.dharmais.co.id/10-01-2007

Illich, Ivan. 1995. Batas-Batas Pengobatan; Perampasan Hak untuk Sehat. Jakarta: Yayasan Obor Indonesia.

Indah Suksmaningsih: http://www.pikiranrakyat.com./10-01-2007

Liliweri, Alo. 2007. Dasar-Dasar Komunikasi Kesehatan. Yogyakarta: Pustaka Pelajar.

Mulyana, Deddy. 1999. Nuansa-Nuansa Komunikasi, Meneropong Politik dan Budaya Komunikasi Masyarakat Kontemporer, Bandung: Remadja Rosdakarya. . 2004 a. Komunikasi Efektif; Suatu Pendekatan Lintasbudaya. Bandung: Remadja Rosdakarya.

2004 b. Komunikasi Populer; Kajian Komunikasi dan Budaya Kontemporer, Bandung: Pustaka Bani Quraisy.

2007. Ilmu Komunikasi Suatu Pengantar. Edisi Revisi. Bandung: Remadja Rosdakarya.

Mulyana, Deddy \& Jalaluddin Rakhmat (ed). 2005. Komunikasi Antar Budaya; Panduan Berkomunikasi dengan Orang-Orang Berbeda Budaya. Bandung: Remadja Rosdakarya. 
Sumpena, Asep. 2002. "Hemodialisis." Diktat Pelatihan. Bandung: RS.Ny.R.A Habibie.

Suryani. 2006. Komunikasi Terapeutik; Teori dan Praktek. Jakarta: Penerbit Buku Kedokteran EGC.

Tamturi, Anas.2006. Komunikasi dalam Keperawatan. Jakarta: Penerbit Buku Kedokteran EGC.
Timmermans, Karin. 2001.ASEAN Worshop; TRIPS, $C B D$ and Traditional Medicines: Concepts and Questions. Jakarta.

Veronica: http://www.pikiran-rakyat.com./10-012007 